\title{
Ichthyofauna as an environmental quality indicator of the Bertioga Channel, São Paulo (Brazil)
}

\author{
June Ferraz Dias*, Maria Luiza Flaquer da Rocha, Thassya Christina dos Santos Schmidt, \\ Bárbara Capelari Villamarin, Diego Barbosa Morais
}

Instituto Oceanográfico Universidade de São Paulo

(Praça do Oceanográfico 191, Cidade Universitária, 05508-120, São Paulo, Brazil)

*Corresponding author: junedias@usp.br

\section{Abstract}

The aim of this study was to investigate the ichthyofauna structure in the region of the north outfall of the Bertioga Channel (São Paulo, Brazil) and the possible effects of the environmental quality loss. The samples were collected in a monthly basis, from September to December 2005, at two oceanographic stations with an otter-trawl. The fish fauna structure was evaluated by ecological indicators and the environmental quality evaluated by the $\mathrm{ABC}$ analysis and the Estuarine Fish Communities Index (EFCI). A total of 1553 individuals from 50 species were sampled. Ariidae and Sciaenidae amounted to $60 \%$ and Cathorops spixii represented $36 \%$ of all specimens collected. The highest richness and ecological diversity were recorded in December, while the highest numerical abundance was found in October. The majority of the species were represented by juveniles. The cluster analysis and canonical correspondence analysis showed a consistent and clear difference between the sampling stations, and the abiotic factors analyzed (temperature, depth and salinity) do not seem to have influence on the community structure. The $\mathrm{ABC}$ analysis suggested a moderate disturbed environment and the EFCI allowed classifying the area as "poor", due to the 12 metrics analyzed, concerning the reduction of the species diversity, composition and abundance, and modifications in the nursery function and trophic integrity of the area. Future studies should focus on jointly analyze chemical indicators of water and sediment with the biological indicators, to confirm the ichthyofaunal condition of the north outfall of the Bertioga Channel.

Descriptors: Fish fauna, Environmental integrity, Bertioga Channel, Southeastern Brazilian coast.

\section{RESUMo}

O objetivo deste estudo foi investigar a estrutura da ictiofauna na região da desembocadura norte do Canal de Bertioga (São Paulo, Brasil) e os possíveis efeitos da perda da qualidade ambiental. As amostras foram coletadas mensalmente de setembro a dezembro de 2005, em duas estações oceanográficas, com rede de arrasto. A estrutura da fauna de peixes foi avaliada por indicadores ecológicos e a qualidade ambiental por curvas $\mathrm{ABC}$ e um índice de comunidades de peixes estuarinos (EFCI). Um total de 1553 indivíduos em 50 espécies foi amostrado. Ariidae e Sciaenidae totalizaram 60\% e Cathorops spixii representou $36 \%$ de todos os espécimes coletados. Maior riqueza e diversidade ecológica foram registradas em dezembro, enquanto a maior abundância numérica foi encontrada em outubro. A maioria das espécies foi representada por juvenis. As análises de agrupamento e de correspondência canônica mostraram uma diferença consistente e clara entre as estações de amostragem, e os fatores abióticos analisados (temperatura, profundidade e salinidade) parecem não ter influência sobre a estrutura da comunidade. A curva ABC sugeriu um ambiente moderadamente perturbado e o EFCI permitiu classificar a área como "pobre", a partir das 12 métricas analisadas, que consideraram a redução da diversidade específica, a composição e a abundância, bem como a modificação na função de berçário/infantário e a integridade trófica da área. Futuros estudos devem se concentrar em analisar conjuntamente os indicadores químicos da água, do sedimento e os indicadores biológicos, para confirmar a condição da ictiofauna da desembocadura norte do $\mathrm{Ca}-$ nal de Bertioga.

Descritores: Fauna de peixes, Integridade ambiental, Canal de Bertioga, Costa sudeste do Brasil. 


\section{INTRODUCTION}

Marine and estuarine ecosystems have important characteristics and functions in coastal water environments. Among the most notable features are the high primary and secondary productivity of estuaries, associated with high richness, abundance, biomass and diversity of fish and invertebrates (BECK et al., 2001; BARLETTA et al., 2008; BARLETTA; COSTA, 2009). In estuaries also occur fundamental biological processes, such as spawning, recruitment, migration and connectivity between the terrestrial and aquatic environments. Estuaries are important sites used as growth areas for juveniles of many fish species that leave the area when they reach maturity (VASCONCELOS et al., 2008).

Several indices have been used to assess the ecological quality of coastal ecosystems using fish as indicators, based on ecological guilds. MARTINHO et al. (2008) describe and compare 6 indices and verified that all of them gave consistent results, but diagnosed as the most adequate the EDI (Estuarine Demersal Indicators) (BORJA et al., 2004) and the TFCI (Transitional Fish Classification Index) (COATES et al., 2007). However, some metrics used in these two indices are not available for Brazilian coastal areas and in particular to the Bertioga Channel, as pollution indicator species, introduced species, fish health and indicator species.

In the Brazilian coast, ecological quality assessment using indices were applied to estuarine environments such as the Paranaguá Estuarine Complex - Paraná (FALCÃO et al., 2008; OTERO et al., 2006), and the Todos os Santos Bay - Bahia (DIAS et al., 2011).

The ichthyofauna of Brazilian estuaries have been studied under various aspects, such as its composition and abundance (FELIX et al., 2006, DIAS et al., 2011), diversity (CASTRO, 2001; CARVALHO NETO; CASTRO, 2008; BARLETTA et al., 2003), assemblages (CONTENTE et al., 2010; ARAÚJO et al., 2013; HOSTIM-SILVA et al., 2013; PASSOS et al., 2013), resource exploitation (BARLETTA; COSTA, 2009), structure and seasonal dynamics of ichthyoplankton (BARLETTA-BERGAN et al., 2002; PORCARO et al., 2014), influence of environmental variables on fish distribution (BARLETTA et al., 2005; BARLETTA et al., 2008), recruitment (BOLZAN et al., 2014), biological and socioeconomic aspects of fisheries exploitation (CHAVES et al., 2003), and also as indicator of environmental quality (VIANA; LUCENA FRÉDOU, 2014). The main hydrographic characteristics of estuaries that influence the fish distribution are salinity, temperature, turbidity and dissolved oxygen (BLABER; BLABER, 1980; BARLETTA et al., 2008).

An ichthyofauna inventory of the Bertioga Channel was recently published, presenting 78 species, 67 genera and 39 families, caught by 10 different fishing techniques (BARBANTI et al., 2013). To the same area, ROCHA and DIAS (2015), using only otter-trawling samples, added fifteen species to the inventory of BARBANTI et al., (2013). On the other hand, PORCARO et al. (2014) described the distribution of the sciaenid larvae in the estuarine system and adjacent continental shelf off Santos, highlighting the region as a Sciaenidae spawning area.

In spite of its ecological importance, urban development in the region associated to fisheries, mariculture and tourism have brought the contribution of waste influx, generating deposits and contaminating surface sediments along the Bertioga Channel, with environmental degradation of the region in the last decades (EICHELER et al., 2007; GONÇALVES et al., 2013).

Among the studies regarding contamination in the Bertioga Channel are LAMPARELLI et al. (2001) that found levels of mercury between TEL and PEL in the sediment of the Bertioga Channel, next to the Santos Channel; ABESSA et al. (2008) that ranked the Bertioga Channel as the third most contaminated area in Santos Estuarine System based on integrative approach of both environmental factors and contaminants; SILVA et al. (2011) that found high values of zinc and arsenic in the region of the Santos Estuarine System; BORDON et al. (2011) that foud mercury concentrations above TEL limit levels in sediment of the north outfall of the Bertioga Channel and other metal contamination confirmed for the bentic ecosystem of the Santos Estuarine System; GONÇALVES et al. (2013) that found no significant levels of contaminants in the channel but arsenic; and SOUSA et al. (2014), who performed the most recent survey in the channel, found cadmium in concentration levels above TEL as well as LABs (linear alkylbenzene sulfonates), which indicates the presence of household sewage and aromatic cyclic hydrocarbons.

The aim of this study was to investigate the viability of the ichthyofauna structure as an indicator of the environmental quality of the Bertioga Channel, Brazil. 


\section{MATERIAL AND METHODS}

\section{STUDY AREA}

The Santos region, central coast of São Paulo State (Brazil), has the port of Santos and the Cubatão industrial park. The introduction of effluents in the estuarine system and the dredging of the port channel, due to the intensification of human activities, can be associated with the environmental quality loss (LAMPARELLI et al., 2001).

The Bertioga Channel is located at the eastern end of the Santos region and is considered a secondary connection to the ocean of the estuarine system of Santos - São Vicente. The Channel is $25 \mathrm{~km}$ long with an average depth between 3-6 $\mathrm{m}$ with a width ranging from 200 to $700 \mathrm{~m}$.

The North Channel opening presents greater depths and receives the influence of the continental shelf waters (MIRANDA et al., 1998; EICHLER et al., 2004). The salinity varies from 24-33 to 20-33 during the winter and summer (EICHLER et al., 2004). It presents microtidal regime and mixed tides are predominantly semidiurnal, with amplitude ranging from $0.7 \mathrm{~m}$ to $1.5 \mathrm{~m}$. The sediments from the river inflow are deposited by the action of tidal currents, which also remobilizes sediment into the channel (FÚLFARO; PONÇANO, 1976), but sandy sediment dominates the areas of the Channel adjacent to the Atlantic Ocean (EICHLER et al., 2007). The Bertioga Channel is classified as a partially mixed estuary type, due to its geomorphological characteristics and the variability of its physical properties (MIRANDA et al., 1998).

\section{SAMPLING AND DATA PROCESSING}

The samples were collected monthly from September to December 2005 in the north outfall of the Bertioga Channel at two oceanographic stations, displaced 3.5 to $4 \mathrm{~km}$ from each other (Figure 1). An otter-trawl, with 40 $\mathrm{mm}$ of mesh size in the arms, $30 \mathrm{~mm}$ in the bagger, and $11 \mathrm{~m}$ length, was used for fish sampling. The effort unit used was a 10 minutes trawl at two knots. Trawling depths varied between 3 and $6 \mathrm{~m}$ depending on the local depth. Temperature and salinity data from the water column were obtained with a CTD (Conductivity, Temperature and Depth probe).

In the laboratory, the collected specimens were identified with taxonomic identification keys (FIGUEIREDO; MENEZES, 1978, 1980, 2000; MENEZES; FIGUEIREDO, 1980, 1985; CARPENTER, 2002a, b; MARCENIUK, 2005; GOMES et al., 2010) and the CATALOG OF FISHES (CAS, 2015), FROESE and PAULY (2015), WORLD REGISTER OF MARINE SPECIES (WorMS, 2015), MARCENIUK and MENEZES (2007) and MENEZES et al. (2015) to update the nomenclature. After identification, individual data were obtained: total length (TL) (in $\mathrm{mm}$ ) with ichthyometer, total weight (TW) and gonad weight $(\mathrm{GW})(\mathrm{g})$ with a semi-analytical scale. Sex identification was based on the gonad description, according with VAZZOLER (1996). The identification of female maturity stages followed the scale described by DIAS et al. (1998), with the group of stages B (in maturation), C (mature), D (hydrated/ spawning) and E (spawned) characterized as adults. Males were classified as juvenile or adults, based in VAZZOLER (1996). Sex ratio was evaluated by $\chi^{2}$ test with 1 degree of freedom and 0.05 significance $\left(\chi^{2}<3.84\right)$, to check for possible differences between the number of males and females sampled. When possible, the length of first maturation $\left(\mathrm{L}_{50}\right)$ was estimated according to KING (1995) for females, to separate juveniles from adults.

\section{DATA ANALYSIS}

The Whitfield index (WHITFIELD, 1994) was used to quantify synthetically the assemblies (WI=number of fish species/number of fish families). The structure of fish fauna was described using the following indicators: Simpson dominance index $(\lambda)$; diversity of Shannon and Weaver (H'); Margalef richness (R) and Pielou evenness (J) (BEGON et al., 2006). These indicators were applied monthly and spatially. The frequency of occurrence was calculated, based on the following classification: constant species $(C \geq 50)$, accessory species $(25>C<50)$ and incidental species $(\mathrm{C} \leq 25)$ (DAJOZ, 1973).

To access the distribution patterns, the cluster analysis using Bray-Curtis similarity was applied to the overall fish composition by months and stations. The canonical correspondence analysis (CCA) was used to identify the most important environmental variable which influences the structure of the fish community. The CCA was used for abundance data for the most important species (about $96 \%$ of total registered). The environmental variables analyzed were depth, temperature and salinity. The data were $\log (\mathrm{x}+1)$ transformed. The canonical correspondence analysis was also applied to investigate the distribution patterns of fish community compared to the month and station. The Spearman correlation coefficient was used 


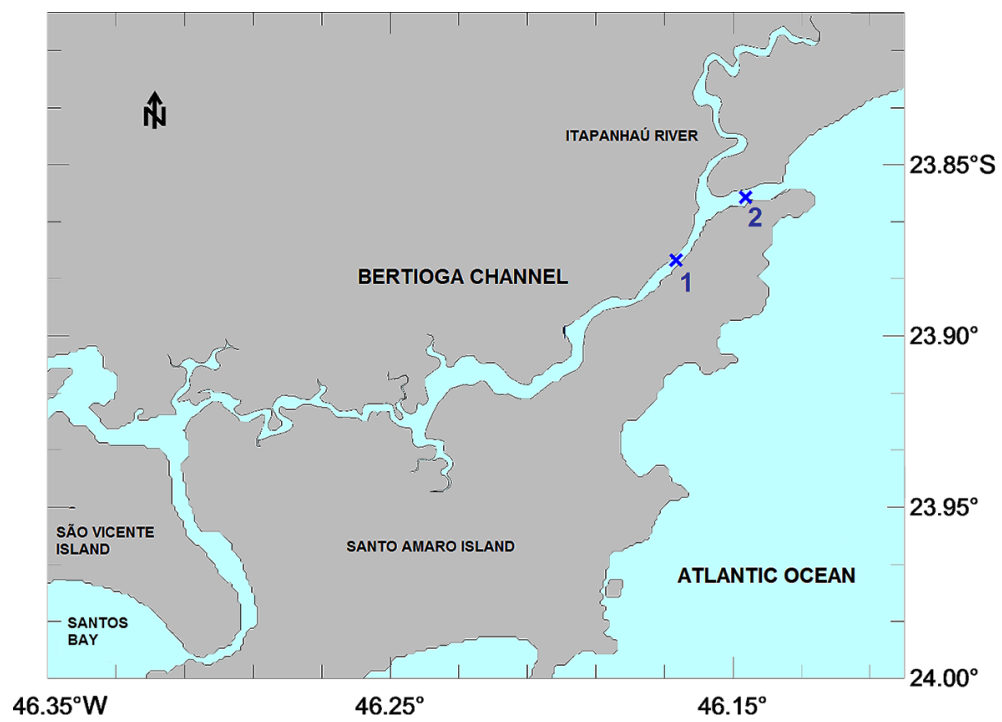

Figure 1. Study area showing the oceanographic stations in the North end of the Bertioga Channel.

to determine if there were differences between fish abundance and environmental variables (ZAR, 1999).

The comparison between the collection sites concerning species was carried out by a non-metric ordering technique (nMDS) with data transformed by $\log _{10}(\mathrm{x}+1)$ withdrawing the rare species, and the Bray-Curtis similarity coefficient. The significance of differences was tested by Similarity Analysis (ANOSIM). The species with the greatest dissimilarity between sampling stations were tested for similarity percentages (SIMPER) (CLARKE; WARWICK, 2001).

The $\mathrm{ABC}$ analysis, or curves of cumulative percentage abundance and biomass by species ordered, was calculated for the total area to verify the environmental integrity. This ratio relates the overlap of the abundance and biomass curves and allows an interpretation of the environmental condition based on the fauna (WARWICK et al., 1987; OTERO, 2006; GONÇALVES; BRAGA, 2008). This is a method for assessing the status of polluted areas based in local populations, without the need for reference of the temporal or spatial series of controlled samples (WARWICK, 1986). The value of W statistical, that measures the difference between the abundance and biomass lines on an $\mathrm{ABC}$ plots, was also provided.

To assess the ecological quality status of the Bertioga Channel, a modified Estuarine Fish Community Index (EFCI) was applied. The EFCI was developed by HARRISON and WHITFIELD (2004) and is described in MARTINHO et al. (2008). This index is conceptually simple and is based on the idea that attributes of fishes, over time, are good indicators of ecosystem health such as the reduction of the species diversity, composition and abundance, and modifications in the nursery function and trophic integrity of the ecosystem. Species from all Families were included. The list of endangered species of the Brazilian fauna (MMA-445, published in December 17, 2014), was referred to check the threatened species. The feeding mode and estuarine use were based on descriptions of ELLIOT et al. (2007), and the data about diet to classify the species in trophic function groups were accessed in Fishbase (FROESE; PAULY, 2015). The species were not classified in subcategories as proposed by (ELLLIOT et al. 2007), in order to generalize the aspects of the trophic guilds or use of the area by the species. Due to the absence of reference data, metric related to a reference communities were not applied.

The EFCI is calculated as the sum of the scores (MARTINHO et al., 2008) and in this study the maximum value was reduced from the original 70 to 60 , due to the lack of two metrics. So, the five thresholds were recalculated in order to better compare values: Very Poor (EFCI $<17)$, Poor $(19 \geq \mathrm{EFCI} \leq 33)$, Moderate $(35 \geq \mathrm{EFCI}$ $\leq 39)$, Good $(41 \geq \mathrm{EFCI} \leq 54)$ and Very Good $(54 \geq \mathrm{EFCI}$ $\leq 60)$.

\section{RESULTS}

In the Bertioga Channel, the mean salinity per station ranged from 26.2 to 33.7, whereas mean temperature from 21.5 to $25.8^{\circ} \mathrm{C}$ (Figure 2). Two patterns in the distribution 


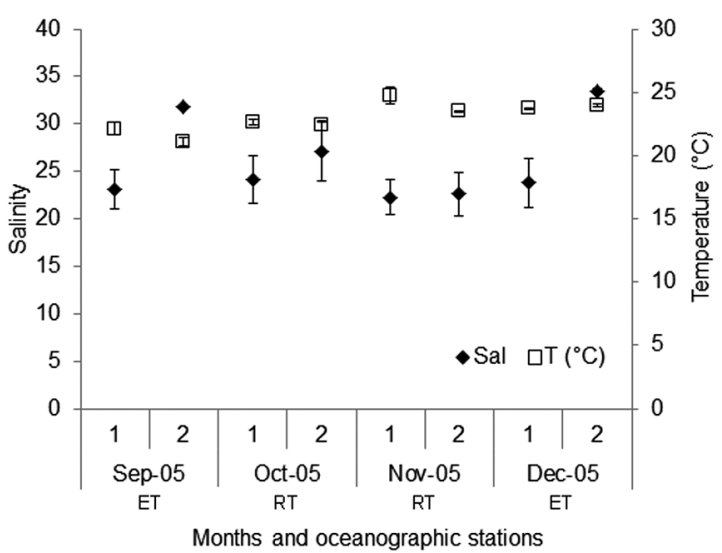

Figure 2. Mean and standard deviation values of temperature $\left(\mathrm{T}^{\circ} \mathrm{C}\right)$ and salinity from September to December 2005 in each oceanographic station (1 and 2) and by month, in the Bertioga Channel. ET=ebb tide; $\mathrm{RT}=$ rising tide.

of salinity could be found, with lower values at inner station (\#1) and the higher values associated with outer station (\#2). Over the months, the salinity showed two peaks, one in September and another in December, both in station 2, related to the ebb tides. Regarding salinity in the water column, station 1 and two months of station 2 presented a pattern, with the stratified halocline between the surface less saline water (21.5) and the bottom layer (26.5), even in a channel as shallow as Bertioga Channel (Figure 3). This pattern with a sharp boundary that separates an upper less salty layer from an intruding wedge-shaped salty bottom layer characterizes a salt wedge estuary. Moreover, in September and December at station 2 the water column was homogeneous, with high salinity, indicating higher influence of coastal adjacent waters at the Channel's outfall during ebb tides.

The mean temperature showed small variation, with the highest values recorded in November and December (Figure 2). There is a general trend of a gradual increase at the temperature of the water column over the months in the two stations, where September had cooler temperatures and December had the warmest (Figure 3). The bottom layer, less saline, it is also colder.

A total of 1553 individuals represented by 50 species and 22 families were collected, totalizing $56017.52 \mathrm{~g}$. The most abundant families were Ariidae (32.7\%), Sciaenidae (26.5\%), Trichiuridae (7.7\%) and Carangidae (6.7\%) (Table 1). Ten species represented approximately $75 \%$ of the catch in number: Cathorops spixii, Stellifer rastrifer, Genidens genidens, Trichiurus lepturus, Chloroscombrus chrysurus, Achirus lineatus, Micropogonias furnieri, Aspistor luniscutis, Stellifer stellifer and Etropus crossotus.
C. spixii showed the highest numerical abundance, with 508 (or $32.7 \%$ ) specimens collected.

Catfishes and sciaenids, except $M$. americanus, had the highest abundance in station 1, while T. lepturus and C. chrysurus were the most abundant species in station 2. Achirus lineatus and Lagocephalus laevigatus were captured on both stations, but with different abundances.

Regarding the population dynamics, five species showed significant differences in the overall sex ratio: M. furnieri, A. luniscutis, S. stellifer, C. spilopterus, B. ronchus (Table 2). Proportion of males was higher in three species analyzed (G. genidens, B. ronchus and $M$. americanus). The majority of the species were represented by juveniles, which have not reached the length and/ or maturity to discriminate the gender. C. chrysurus, $P$. corvinaeformis, L. laevigatus, O. oglinum, S. tessellatus and $L$. lagocephalus presented only juveniles specimens.

It was possible to estimate the first maturation average length of catfishes C. spixii $\left(\mathrm{L}_{50}=121.2 \mathrm{~mm}\right)$, G. genidens $\left(\mathrm{L}_{50}=180.2 \mathrm{~mm}\right)$ and A. luniscutis $\left(\mathrm{L}_{50}=111.9 \mathrm{~mm}\right)$, and sciaenids $S$. rastrifer $\left(\mathrm{L}_{50}=89 \mathrm{~mm}\right)$ and $S$. stellifer $\left(\mathrm{L}_{50}=106.2 \mathrm{~mm}\right.$ ) (Table 2).

The Whitfield index for total samples was 2.27, whereas in the inner station (\#1) was 2.22 and in the outer station (\#2) was 1.60. Results from station 2 reflects the lower number of species and higher of families in the outfall of the Channel.

Highest number of species, ecological diversity and richness were recorded in December, while the highest numerical abundance was found in October (Table 3). Between oceanographic stations, the highest richness, abundance, dominance and evenness were recorded at station 1 (inner station), which also presents about $70 \%$ of fish sampled in this study. In spite of being close to each other, station 2 is in the channel outfall, and presents estuarine and marine representative species.

The results of cluster analysis, nMDS and canonical correspondence analysis showed a consistent and clear difference between the sampling stations, despite they are only $3.5 \mathrm{~km}$ from each other (Figures 4 and 5). The station groups were formed by combining the number of stations separately (1 and 2 ) within four months. The canonical correspondence analysis of species distribution between the oceanographic stations showed a pattern which ten species are correlated mainly with the inner station (station 1), especially for the catfish species (C. spixii, $G$. genidens, A. luniscutis and G. barbus) and sciaenids ( $S$. rastrifer, M. furnieri, S. stellifer and B. ronchus), and ten 

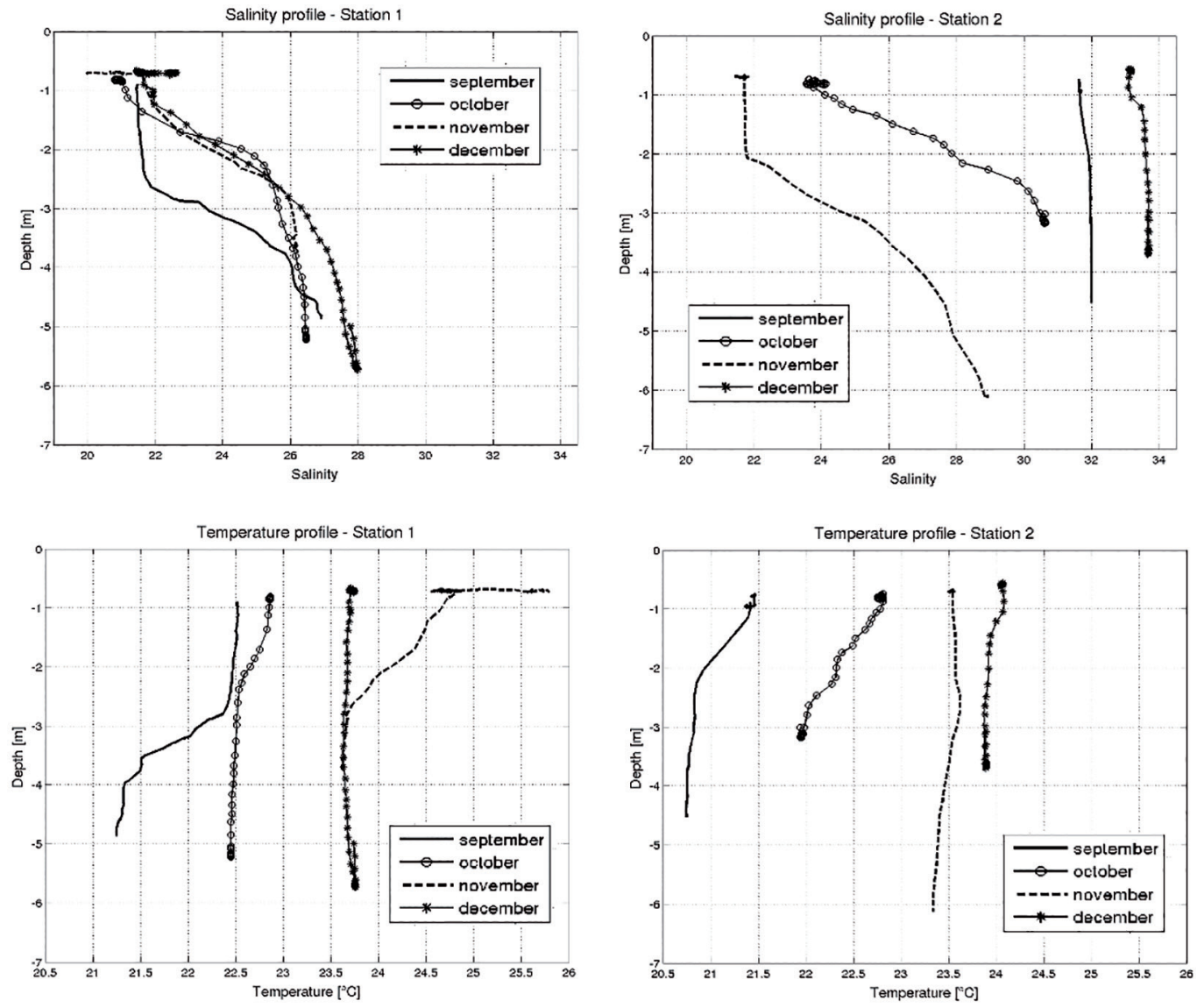

Figure 3. Temperature ( $a$ and b) and salinity (c and d) profiles from oceanographic stations 1 and 2 in the Bertioga Chanel, from September to December 2005.

species correlated with station 2, including the pelagic $C$. chrysurus, H. clupeola, L. laevigatus, A. lepidentostole, two flatfishes - C. spilopterus and E. crossotus, and the demersal species $M$ americanus, $P$. prunctatus and $P$. corvinaeformis, essentially marine migrants. The Similarity Percentage Analysis (SIMPER) identified the contribution of each fish species between oceanographic stations, and also determined its contribution to dissimilarity within groups. Catfishes C. spixii, G. genidens, A. luniscutis and the sciaenid $S$. rastrifer were the most contributed to the dissimilarity between the groups, since occurring almost exclusively in the inner station.

The abiotic factors analyzed (temperature, depth and salinity) seem to have no influence on the species distribution, as showed by the canonical correspondence analysis and the correlation coefficient of Spearman; however, it was possible to observe a pattern of species distribution related to abiotic factors, i.e., the species $P$. punctatus was related to temperature. $H$. clupeola, $M$. furnieri and $P$. harroweri were related to salinity, and $C$. spixii and A. lineatus with depth (Figure 6).

The $\mathrm{ABC}$ analysis for the whole area presented curves of cumulative abundance and biomass very close and parallel, with some parts of the biomass curve falling below the number curve suggesting a moderate disturbed environment (Figure 7), same pattern of the inner station. Station 1 also presented the lowest value of W-statistic.

The Bertioga Channel is dominated by three species of estuarine resident catfishes, mainly C. spixii, and by the sciaenid $S$. rastrifer. The values of the metrics calculated and the classification in the score thresholds presented (see Material and Methods section) regarding the species diversity, composition and abundance, the nursery function and the trophic integrity of the area allowed to classify the quality of the area as "Poor", due to the values 
Table 1. List of species collected at the Bertioga Channel between September and December 2005, with species code and abundances at station \#1 and \#2.

\begin{tabular}{|c|c|c|c|c|}
\hline Family & Species & Species Code & \# $1(\%)$ & $\# 2(\%)$ \\
\hline \multirow{4}{*}{ ENGRAULIDAE } & Anchoa januaria (Hildebrand, 1943) & ANJA & $<0.5$ & 0 \\
\hline & Anchoviella lepidentostole (Fowler, 1941) & ANLE & 0.6 & 3.3 \\
\hline & Centegraulis edentulus (Cuvier, 1829) & CEED & $<0.5$ & 2 \\
\hline & Lycengraulis grossidens (Agassiz, 1829) & LYGR & $<0.5$ & $<0.5$ \\
\hline PRISTIGASTERIDAE & Pellona harroweri (Fowler, 1919) & PEHA & 2.5 & $<0.5$ \\
\hline \multirow{2}{*}{ CLUPEIDAE } & Harengula clupeola (Cuvier, 1829) & HACL & 0.5 & 3.3 \\
\hline & Opisthonema oglinum (Lesueur, 1818) & OPOG & 0 & 2.2 \\
\hline \multirow{4}{*}{ ARIIDAE } & Aspistor luniscutis (Valenciennes, 1840) & ASLU & 5.8 & 0 \\
\hline & Cathorops spixii (Agassiz, 1829) & CASP & 22.3 & 0 \\
\hline & Genidens barbus (Lacepède, 1803) & GEBA & 2.5 & 0 \\
\hline & Genidens genidens (Valenciennes, 1840) & GEGE & 15.6 & 0 \\
\hline SYNODONTIDAE & Synodon foetens (Linnaeusm 1766) & SYFO & 0 & $<0.5$ \\
\hline MUGILIDAE & Mugil curvidens (Valenciennes, 1836) & MUCU & 0 & $<0.5$ \\
\hline FISTULARIA & Fistularia tabacaria (Linnaeus, 1758) & FITA & 0 & $<0.5$ \\
\hline TRIGLIDAE & Prionotus punctatus (Bloch, 1793) & PRPU & $<0.5$ & 4.2 \\
\hline \multirow{2}{*}{ CENTROPOMIDAE } & Centropomus parallelus (Poey, 1860) & CEPA & $<0.5$ & $<0.5$ \\
\hline & Centropomus undecimalis (Bloch, 1796) & CEUN & $<0.5$ & $<0.5$ \\
\hline \multirow{2}{*}{ SERRANIDAE } & Diplectrum radiale (Quoy \& Gaimard, 1824) & DIRA & 0 & 1.1 \\
\hline & Rypticus sp. (Cuvier \& Valenciennes, 1829) & RYSP & $<0.5$ & 0 \\
\hline \multirow{2}{*}{ CARANGIDAE } & Chloroscombrus chrysurus (Linnaeus, 1766) & $\mathrm{CHCH}$ & 0.8 & 20.1 \\
\hline & Selene vomer (Linnaeus, 1758) & SEVO & $<0.5$ & $<0.5$ \\
\hline \multirow{3}{*}{ GERREIDAE } & Diapterus auratus (Ranzani, 1842) & DIOL & 0 & $<0.5$ \\
\hline & Diapterus rhombeus (Valenciennes, 1830) & DIRH & 0 & $<0.5$ \\
\hline & Eucinostomus gula (Quoy \& Gaimard, 1824) & EUGU & $<0.5$ & 0 \\
\hline HAEMULIDAE & Pomadasys corvinaeformis (Steindachner, 1868) & POCO & 0 & 7.1 \\
\hline \multirow{9}{*}{ SCIAENIDAE } & Bairdiella ronchus (Cuvier, 1830) & BARO & 2.6 & 0 \\
\hline & Isopisthus parvipinnis (Cuvier, 1830) & ISPA & $<0.5$ & $<0.5$ \\
\hline & Larimus breviceps (Cuvier, 1830) & LABR & $<0.5$ & 0 \\
\hline & Menticirrhus americanus (Linnaeus, 1758) & MEAM & $<0.5$ & 4.6 \\
\hline & Micropogonias furnieri (Desmarest, 1823) & MIFU & 6.7 & $<0.5$ \\
\hline & Ophioscion punctatissimus (Meek \& Hildebrand, 1925) & OPPU & $<0.5$ & 0 \\
\hline & Paralonchurus brasiliensis (Steindachner, 1875) & PABR & $<0.5$ & 0 \\
\hline & Stellifer rastrifer (Jordan, 1889) & STRA & 20.6 & $<0.5$ \\
\hline & Stellifer stellifer (Bloch, 1790) & STST & 4.7 & 0 \\
\hline EPHIPPIDIDAE & Chaetodipterus faber (Broussonet, 1782) & CHFA & 2.0 & 1.3 \\
\hline TRICHIURIDAE & Trichiurus lepturus (Linnaeus, 1758) & TRLE & 0.8 & 24.3 \\
\hline \multirow{2}{*}{ PARALICHTHYIDAE } & Citharichthys spilopterus (Günther, 1880) & CISP & 1.5 & 3.1 \\
\hline & Etropus crossotus (Jordan \& Gilbert, 1882) & ETCR & $<0.5$ & 6.9 \\
\hline \multirow{3}{*}{ ACHIRIDAE } & Achirus declives (Chabanaud, 1940) & ACDE & $<0.5$ & 0 \\
\hline & Achirus lineatus (Linnaeus, 1758) & ACLI & 5.4 & 5.1 \\
\hline & Trinectes paulistanus (Miranda Ribeiro, 1915) & TRPA & $<0.5$ & 0 \\
\hline CYNOGLOSSIDAE & Symphurus tesselatus (Quoy \& Gaimard, 1824) & SYTE & 0.5 & 0.7 \\
\hline MONACANTHIDAE & Stephanolepis hispidus (Linnaeus, 1766) & STHI & 0 & $<0.5$ \\
\hline \multirow{6}{*}{ TETRAODONTIDAE } & Lagocephalus laevigatus (Linnaeus, 1766) & LALA & 1.1 & 3.3 \\
\hline & Lagocephalus lagocephalus (Linnaeus, 1758) & LALAg & 0.7 & 0 \\
\hline & Sphoeroides greeleyi (Gilbert, 1900) & SPGR & 0.4 & 2,2 \\
\hline & Sphoeroides spengleri (Bloch, 1785) & SPSP & $<0.5$ & 0 \\
\hline & Sphoeroides testudineus (Linnaeus, 1758) & SPTE & $<0.5$ & $<0.5$ \\
\hline & Sphoeroides tyleri (Shipp, 1974) & SPTY & 0 & $<0.5$ \\
\hline DIODONTIDAE & Chilomycterus spinosus (Linnaeus, 1758) & CYSP & $<0.5$ & $<0.5$ \\
\hline
\end{tabular}


Table 2. Maximum (TL max) and minimum (TL min) total lengths, mean length of first maturity, sex ratios and percentage of juveniles of fourteen species collected in the Bertioga Channel in 2005.

\begin{tabular}{|c|c|c|c|c|c|}
\hline Species & TL min & TL max & $\mathrm{L}_{50}$ & $\mathrm{M}: \mathrm{F}$ & $\%$ of Juveniles \\
\hline Aspistor luniscutis & 109 & 370 & 111.92 & $0.37: 1^{*}$ & - \\
\hline Genidens genidens & 110 & 294 & 180.2 & $1.35: 1$ & $20.2 \%$ \\
\hline Micropogonias furnieri & 70 & 243 & - & $0.28: 1^{*}$ & $14.8 \%$ \\
\hline Cathorops spixii & 80 & 240 & 121.16 & $0.71: 1$ & $13.9 \%$ \\
\hline Bairdiella ronchus & 138 & 216 & - & $3.3: 1^{*}$ & - \\
\hline Menticirrhus americanus & 70 & 193 & - & $3: 1$ & - \\
\hline Harengula clupeola & 56 & 187 & - & - & $36.8 \%$ \\
\hline Anchoviella lepidentostole & 70 & 180 & - & $0.86: 1$ & - \\
\hline Pomadasys corvinaeformis & 90 & 159 & - & $1: 1$ & $100 \%$ \\
\hline Citharichthys spilopterus & 73 & 157 & - & $0.08: 1^{*}$ & $26.7 \%$ \\
\hline Stellifer stelifer & 76 & 143 & 106.18 & $0.21: 1^{*}$ & - \\
\hline Achirus lineatus & 68 & 135 & 111,7 & - & - \\
\hline Pellona harroweri & 54 & 134 & - & $0.6: 1$ & - \\
\hline Stellifer rastrifer & 68 & 133 & 88.99 & $0.79: 1$ & $5.7 \%$ \\
\hline
\end{tabular}

Table 3. Calculated indices of fish community structure at the different sampling months and sites at the Bertioga Channel.

\begin{tabular}{lcccccc}
\hline $\begin{array}{l}\text { Dates/ Oceanographic } \\
\text { stations }\end{array}$ & $\begin{array}{c}\text { Species } \\
\text { Richness }\end{array}$ & $\mathrm{N}$ & $\begin{array}{c}\text { Simpson } \\
\text { Dominance }(\lambda)\end{array}$ & $\begin{array}{c}\text { Shannon Diversity } \\
\left(\mathrm{H}^{\prime}\right)\end{array}$ & $\begin{array}{c}\text { Margalef Richness } \\
\text { Pielou Evenness } \\
(\mathrm{J})\end{array}$ \\
\hline Sep 30 2005 & 30 & 238 & 0.078 & 2.83 & 5.30 & 0.832 \\
Oct 21 2005 & 32 & 651 & 0.196 & 2.16 & 4.79 & 0.623 \\
Nov 17 2005 & 32 & 380 & 0.129 & 2.63 & 5.22 & 0.760 \\
Dec 16 2005 & 35 & 284 & 0.098 & 2.84 & 6.02 & 0.799 \\
$\# 1$ & 40 & 1101 & 0.132 & 2.45 & 5.57 & 0.633 \\
$\# 2$ & 34 & 452 & 0.122 & 2.59 & 5.40 & 0.735 \\
\hline
\end{tabular}

of the 12 metrics analyzed (Table 4). It agrees with $\mathrm{ABC}$ analysis and dominance of few species.

\section{DISCUSSION}

Estuaries are some of the most heavily used and threatened natural coastal systems. Their ecosystem services as the noncollapsed fisheries, the nursery ground function and the filtering and detoxification function suffer deterioration due to the increasing of the human activities (BARBIER et al., 2011).

The typical fish fauna from estuarine regions is characterized by a high abundance but few dominant species (BLABER et al., 1989). The Bertioga Channel fish community presented 50 species and was dominated by 10 species of Ariidae, Sciaenidae and a Trichiuridae in abundance and biomass. In tropical estuaries the marine catfish species (Ariidae) can be considered the most important fish group in terms of number of species, density and biomass (ARAÚJO et al., 1998;
LOWE-MCCONNELL, 1999; BARLETTA; BLABER, 2007; BARLETTA et al., 2008; BARLETTA et al., 2010). In this study, Ariidae was represented by four species, and C. spixii was the most abundant. This is a similar pattern of other estuarine regions in the Brazilian coast (ARAÚJO et al., 1998; AZEVEDO et al., 1999; SCHWARZ JR. et al., 2006; SCHWARZ, JR. et al., 2007; CARVALHO-NETO; CASTRO, 2008; SCHMIDT et al., 2008), as in other tropical regions, such as Mexico (RUEDA; DEFEO, 2003).

The estuaries act as a reproduction or breeding area for the development of eggs and larvae of many organisms, including fish. Some species use the estuary throughout their life cycle, while others spend the early part of his life there, where there are abundant food and protection from predators, thus increasing their survival, and others use them as escape routes and migration (CHAO et al., 1985; ELLIOTT et al., 2007). In this study, all species in the Bertioga Channel showed overall length below the maximum recorded in the literature (FIGUEIREDO; 


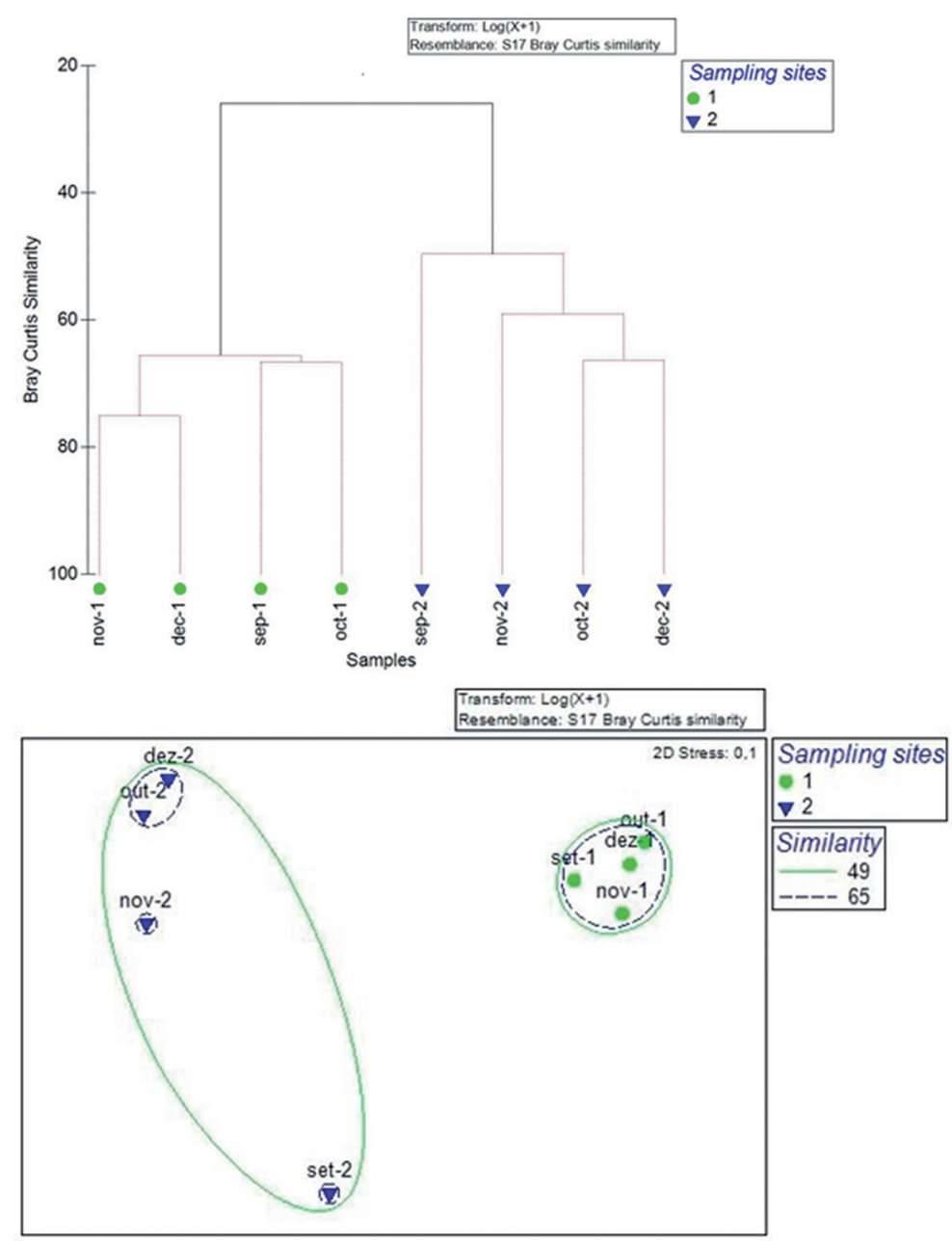

Figure 4. Spatial and temporal cluster of fish assemblages and nMDS plot of the groups from stations 1 and 2 from the Bertioga Channel based on Bray-Curtis similarity.

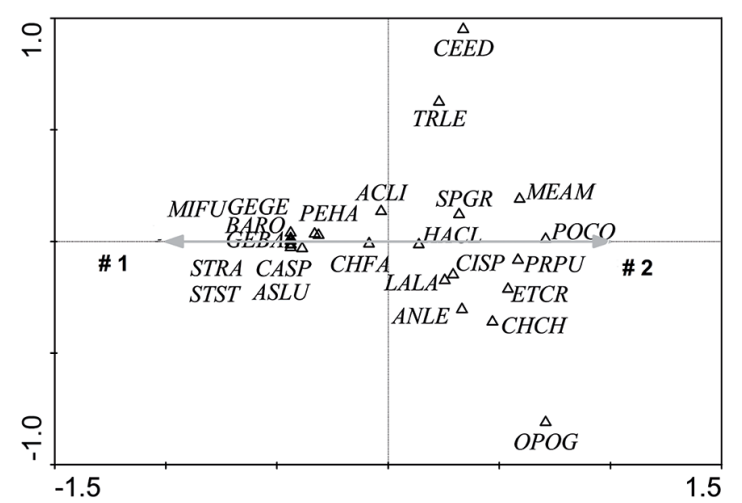

Figure 5. Canonical Correspondence Analysis diagram for oceanografic stations and fish species from the Bertioga Channel in 2005. Codes for fish names are presented in Table 1.
MENEZES, 1978, 1980, 2000; MENEZES; FIGUEIREDO, 1980, 1985; FROESE; PAULY, 2015) suggesting that the region studied is used by most of the species as a growth area. This information is reinforced by the fact that many species captured in this study were characterized only by juveniles such as $C$. chrysurus, $P$. corvinaeformis, $L$. laevigatus, O. oglinum, S. tessellatus and L. lagocephalus.

For only three species of catfish and two Stellifer species was possible to estimate the average length of first maturation $\left(\mathrm{L}_{50}\right)$. According to VAZZOLER (1996), the length of first maturation $\left(\mathrm{L}_{50}\right)$ is a reproductive tactic highly biased by place and sample season, dependent on the growth of individuals, and correlated with environmental conditions prevailing in the area of its occurrence. Its estimate is crucial for understanding the dynamics and 


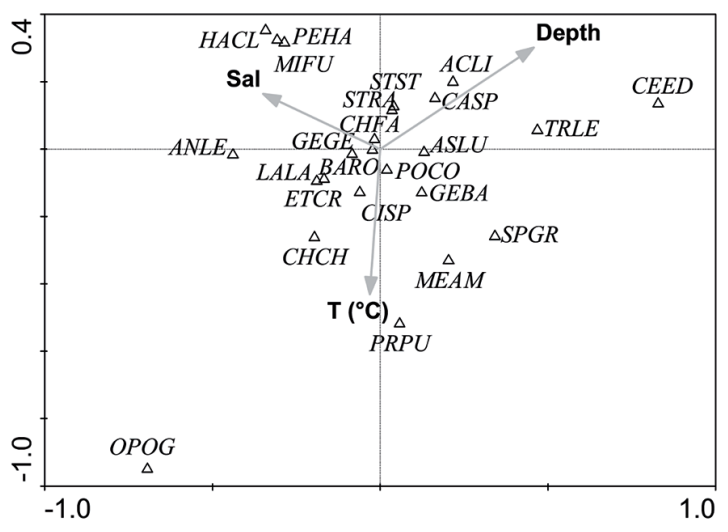

Figure 6. Canonical Correspondence Analysis diagram for environmental factors and the most abundant fish species from the Bertioga Channel. Codes for fish species names are in Table 1.

reproductive growth of both species populations, for economic as well as ecological importance (VAZZOLER, 1996).

The length of first maturation $\left(\mathrm{L}_{50}\right)$ for females of C. spixii was $121.2 \mathrm{~mm}$ in the present study, however in the region of Cananéia was $96 \mathrm{~mm}$ (MISHIMA; TANJI, 1983). For Genidens genidens the value of $\mathrm{L}_{50}$ was 180 $\mathrm{mm}$, higher than that found by BARBIERI et al. (1992) in a pond (RJ) as well as the $133 \mathrm{~mm}$ found in Sepetiba Bay by ARAÚJO et al. (1998). To $S$. rastrifer the $\mathrm{L}_{50}$ was estimated at $89 \mathrm{~mm}$, far below that found in the literature $\left(\mathrm{L}_{50}=95 \mathrm{~mm}\right.$ (COELHO et al., 1985, CAMARGO; ISAAC, 2005). The same pattern was observed for $S$. stellifer, with the length of first maturity estimated at $106 \mathrm{~mm}$, while in the region of Santa Catarina, the $\mathrm{L}_{50}$ was estimated at 75 mm (ALMEIDA; BRANCO, 2002).

Segregation in species distribution was observed between stations, with greater richness, abundance and biomass in a more protected area of the estuary outfall (station 1), with little variation in the temperature and salinity. This preference for the inner region has been reported in other studies, such as ARAÚJO et al. (1998), AZEVEDO et al. (1999), SCHWARZ JR. et al. (2007). According to AZEVEDO et al. (1999) two demersal fish communities were evident, the inner area of the Sepetiba Bay and the other in the outer zone, with occurrence of $G$. genidens and $C$. spixii in the inner and middle area. SCHWARZ JR. et al. (2007) also recorded greater abundance of C. spixii in the inner Pinheiros Bay and high occurrence of I. parvipinnis, S. rastrifer and S. brasiliensis in the outermost area, differing from that found in the present study for Sciaenid species.
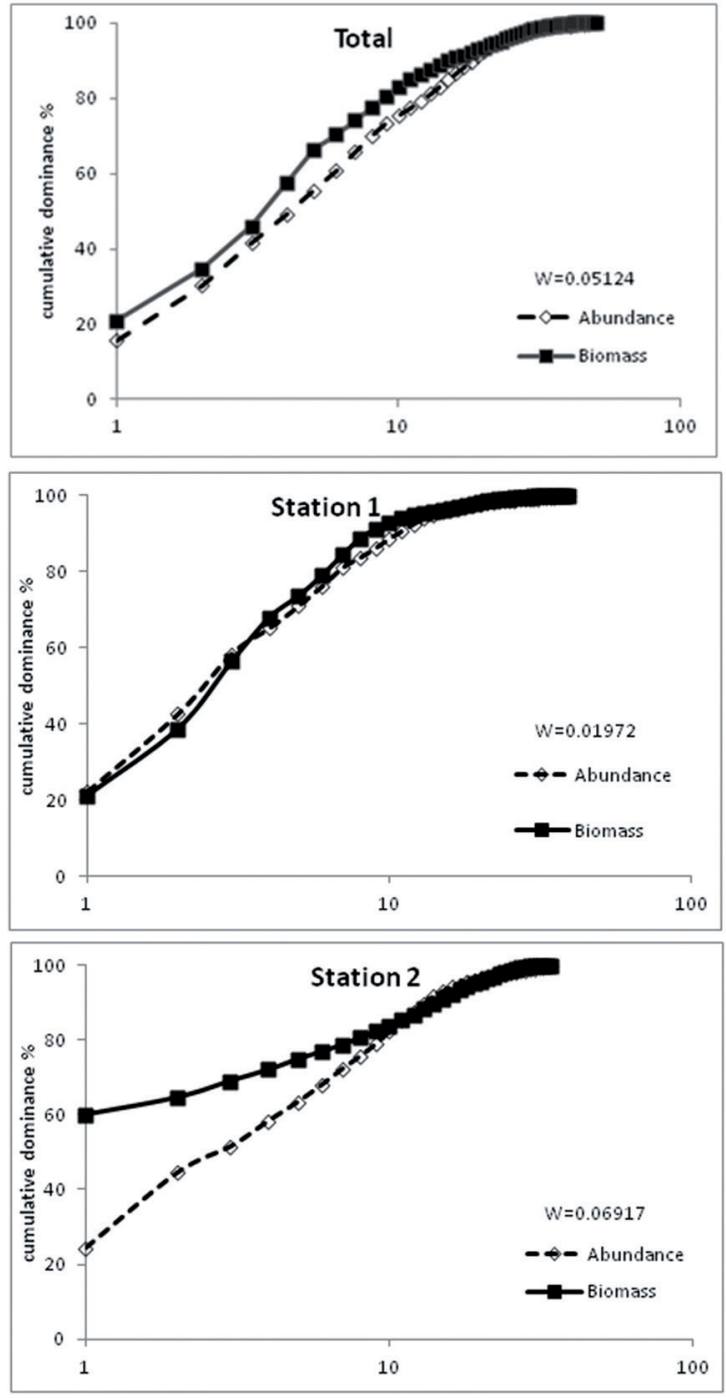

Figure 7. $A B C$ curves of cumulative dominance for the total area (a) and to stations 1 (b) and 2 (c) for fish species caught in the Bertioga Channel.

Estuaries are dynamic systems that exhibit wide fluctuations in environmental conditions (KUPSCHUS; TREMAIN, 2001). The main water quality parameters, such as salinity, temperature, turbidity and dissolved oxygen are known to influence the distribution of fish, although the temperature and salinity are not important for many juveniles (BLABER; BLABER, 1980). According BARLETTA et al. (2008) juveniles and adults of some species respond differently to seasonal fluctuations of environmental factors, and this behavior is seen as a strategy to avoid competition and predators. The Bertioga Channel was occupied mainly for juveniles from coastal and estuarine species. 
Table 4. Metrics of the Estuarine Fish Community Index, respective values and scores to the Bertioga Channel. See text to EFCI classification thresholds.

\begin{tabular}{lcc}
\hline Metric & Value & Score \\
\hline Total number of taxa & 50 & 1 \\
Rare or threatened species & 1 & 1 \\
Exotic or introduced species & 0 & 3 \\
Number of species that make up 90\% of the abundance & 18 & 1 \\
Number of estuarine resident taxa & 3 & 3 \\
Number of estuarine-dependent marine taxa & $35 \%$ & 1 \\
Relative abundance of estuarine resident taxa & $70 \%$ & 5 \\
Relative abundance of estuarine-dependent marine taxa & 14 & 1 \\
Number of benthic invertebrate feeding taxa & 3 & 1 \\
Number of piscivorous taxa & $28 \%$ & 1 \\
Relative abundance of benthic invertebrate feeding taxa & $6 \%$ & 1 \\
Relative abundance of piscivorous taxa & & 1 \\
Classification & & Poor \\
\hline
\end{tabular}

Several studies have described the influence of environmental factors on the distribution of fish species (MARSHALL; ELLIOTT, 1998; ARAÚJO et al., 2002; RUEDA; DEFEO, 2003). In this study, environmental factors measured did not affect the fish community, or distribution over the months. However, there was a correlation of environmental variables with the distribution of some species.

The ABC analysis compares the ranked distribution of abundance among species against the similar distribution of biomass among species. It is based in r-K strategy of life cycle, and considers that under stress condition, the diversity decreases and r-strategist species are dominant (BERVOETS et al., 2005). This method is considered a more useful than the univariate ones and is easily contrasted and interpreted (RICE, 2000). Under stress conditions, there is a competitive balance, the diversity decreases, and the dominant species are $r$-strategists, small size and with short life cycle.

In few months sampled, both stations \#1 and \#2 presented biomass curves below and/or overlapping the abundance curves, suggesting some degree of disturbance, mainly in station 1, despite of the inner station concentrates higher amount of species with K-strategy like catfishes. On the other hand, OTERO et al. (2006) discuss the relationship between abundance/biomass is shown to be directly related to the occurrence of juvenile fish in shallow areas, which is the case of the total area analyzed.

According to WARWICK (1986) the ABC analysis uses local populations to assess the status of an ecosystem, with no references to temporal or spatial series of controlled samples. This is important since pristine areas for comparison are absent in the vicinities. Several authors agree that the ABC analysis should be used in combination with other methods to access quality of aquatic environments, but this index was applied in Brazilian inland waters (PINTO et al., 2006; ROCHA; FREIRE, 2009; DIAS; TEJERINA-GARRO, 2010) as well as in coastal estuarine systems (FALCÃO et al., 2008, OTERO et al., 2006, DIAS et al., 2011). Other indices as the Index of Biotic Integrity - IBI (KARR, 1981) were applied in inland waters (PINTO et al., 2006a, b; PINTO; ARAÚJO, 2007; COSTA; SCHULZ, 2010). A combination of two indicators was preformed only by SOARES et al. (2011) in different impacted tidal creeks of an estuarine area in northern Brazil, and their results indicate that the ecological indices applied reflect the environmental quality and environmental changes in this coastal system.

In combination with the $\mathrm{ABC}$ analysis, the EFCI also classified the Bertioga Channel as poor concerning the integrity of fish community. The EFCI is an ecologically based method that combines both structural and functional attributes of fish communities, providing a robust and sensitive method for assessing the ecological condition of estuarine ecosystems. As explained above, it is not possible to compare our results with other studies.

The main component of fish based indicators is the functional guild. As the knowledge of fish fauna of estuarine and coastal water environments from Brazil 
is partial, mainly due to fragmented information, it is not possible to find a consensus concerning trophic and reproductive functional guilds, and classifications may vary, as discussed by MARTINHO et al. (2008).

The Bertioga Channel is a multi-use area, considered a secondary connection to the ocean of the estuarine system of Santos - São Vicente, which suffers intense pressure from pollution, habitat alteration and overfishing (ROCHA; DIAS, 2015). In spite of few months of sampling and a restricted area, the results are consistent and qualified the north outflow of the Bertioga Channel as moderately disturbed. Only a healthy ecosystem can provide good quality of the water and keep the ecosystem functions and ecosystem services.

In addition, the methods employed presented a diagnosis of the area, so that may be applied to other regions, to provide quick response on environmental conditions, using the fish fauna. Future studies should focus on jointly analyze the results available of chemical studies of water and sediment, with the biological studies of longer terms, to confirm the condition of the Bertioga Channel.

\section{ACKNOWLEDGEMENTS}

The authors would like to thank Dr Mônica ToledoPiza (Biosciences Institute, University of São Paulo). Thanks to Oceanographic Institute of the University of São Paulo (IOUSP) for the use of their facilities and vessels; and the Foundation for Research Support of the State of São Paulo (FAPESP) for sponsoring this research project (ECOSAN Thematic Project - A influência do complexo estuarino da baixada santista sobre o ecossistema da plataforma adjacente, Subproject Ichthyofauna, Proc. N. 03/09932-1). This work was based on the thesis of M.L.F Rocha, defended in 2009. We would like to thank also to the trainees of the ECORREP- IOUSP (Reproductive and Recruitment Ecology of Marine Organisms Lab.) for their help in field work and sorting the specimens.

This work is a tribute to Professor Dr José Lima de Figueiredo, responsible for incalculable contribution to the knowledge of marine fish fauna of southeastern Brazil.

\section{REFERENCES}

ABESSA, D. M. S.; CARR, R. S.; SOUSA, E. C. P. M.; RACHID, B. R. F.; ZARONI, L. P.; GASPARRO, M. R.; PINTO, Y. A.; BÍCEGO, M. C.; HORTELLANI, M. A.; SARKIS, J. E. R.; MUNIZ, P. Integrative Ecotoxicological Assessment of Contaminated Sediments in a Complex Tropical Estuarine
System. In: TOBIAS, N. H. (Org.). Marine Pollution: New Research. $1^{\text {st }}$ ed. New York: Nova Science Publishers, 2008. p. $125-160$.

ALMEIDA, L. R.; BRANCO, J. O. Aspectos biológicos de Stellifer stellifer (Bloch) na pesca artesanal do camarão sete-barbas, Armação do Itapocoroy, Penha, Santa Catarina, Brasil. Rev. Bras. Zool., v. 19, n. 2, p. 601-610, 2002.

ARAÚJO, F. G.; CRUZ-FILHO, A. G.; AZEVEDO, M. C. C.; SANTOS, A. C. A. Estrutura da comunidade de peixes demersais da baía de Sepetiba, RJ. Rev. Bras. Biol., v. 58, n. 3, p. 417-430, 1998.

ARAÚJO, F. G.; AZEVEDO, M. C. C.; SILVA, M. A.; PESSANHA, A. L. M., GOMES, I. D.; CRUZ-FILHO, A. G. Environmental influences on the demersal fish assemblages in the Sepetiba Bay, Brazil. Estuaries, v. 25, n. 3, p. 441-450, 2002.

AZEVEDO, M. C. C.; ARAÚJO, F. G., CRUZ-FILHO, A. G.; GOMES, I. D.; PESSANHA, A. L. M. Variação espacial e temporal de bagres marinhos (Siluriformes, Ariidae) na baía de Sepetiba, Rio de Janeiro. Rev. Bras. Biol., v. 59, n. 3, p. 443-454, 1999.

BARBANTI, B.; CAIRES, R.; MARCENIUK, A. P. A ictiofauna do Canal de Bertioga, São Paulo, Brasil. Biota Neotrop., v. 13, n. 1, p. 276-291, 2013.

BARBIER, E. B.; HACKER, S. D.; KENNEDY, C.; KOCH, E. W.; STIER, A. C.; SILLIMAN, B. R. The value of estuarine and coastal ecosystem services. Ecol. Monogr., v. 81, n. 2, p. 169-193, 2011.

BARBIERI, L. R.; SANTOS, R. P.; ANDREATA, J. V. Reproductive biology of the marine catfish, Genidens genidens (Siluriformes, Ariidae), in the Jacarepaguá Lagoon system, Rio de Janeiro, Brazil. Environ. Biol. Fish., v. 35, n. 1, p. 23-35, 1992.

BARLETTA, M.; AMARAL, C. S.; CORRÊA, M. F. M.; GUEBERT, F.; DANTAS, D. V.; LORENZI, L.; SAINTPAUL, U. Factors affecting seasonal variations in demersal fish assemblages at an ecocline in a tropical-subtropical estuary. J. Fish Biol., v. 73, n. 6, p. 1314-1336, 2008.

BARLETTA, M.; BARLETTA-BERGAN, A.; SAINT-PAUL, U. The role of salinity in structuring the fish assemblages in a tropical estuary. J. Fish Biol., v. 66, n. 1, p. 45-72, 2005.

BARLETTA, M.; BARLETTA-BERGAN, A.; SAINT-PAUL, U.; HUBOLD, G. Seasonal changes in density, biomass, and diversity of estuarine fishes in tidal mangrove creeks of the lower Caeté Estuary (northern Brazilian coast, east Amazon). Mar. Ecol. Progr. Ser., v. 256, p. 217-228, 2003.

BARLETTA, M.; BLABER, S. J. M. Comparision of fish assemblages and guilds in tropical habitats of the Embley (Indo-West Pacific) and Caeté (Western Atlantic) estuaries. Bull. Mar. Sci., v. 80, n. 3, p. 647-680, 2007.

BARLETTA, M.; BLABER, S. J. M. Comparison of fish assemblages and guilds in tropical habitats of the Embley (Indo-West Pacific) and Caeté (Western Atlantic) estuaries. Bull. Mar. Sci., v. 80, n. 3, p. 647-680, 2007.

BARLETTA, M.; COSTA, M. F. Living and non-living resources exploitation in a tropical semi-arid estuary. J. Coast. Res., v. 56, p. 371-375, 2009.

BARLETTA, M.; JAUREGUIZAR, A. J.; BAIGUN, C.; FONTOURA, N. F.; AGOSTINHO, A. A.; ALMEIDA-VAL, V. M. F.; VAL, A. L.; TORRES, R. A.; JIMENES-SEGURA, L. F.; GIARRIZZO, T.; FABRÉ, N. N.; BATISTA, V. S.; LASSO, C.; 
TAPHORN, D. C.; COSTA, M. F.; CHAVES, P. T.; VIEIRA, J. P.; CORREAA, M. F. M. Fish and aquatic habitat conservation in South America: a continental overview with emphasis on neotropical systems. J. Fish Biol., v. 76, n. 9, p. 2118-2176, 2010.

BARLETTA-BERGAN, A.; BARLETTA, M.; SAINT-PAUL, U. Community structure and temporal variability of ichthyoplankton in North Brazilian mangrove creeks. J. Fish Biol., v. 61, n. sA, p. 33-51, 2002.

BECK, M. W.; HECK JR, K. L.; ABLE, K. W.; CHILDERS, D. L.; EGGLESTON, D. B.; GILLANDERS, B. M.; HALPERN, B.; HAYS, C. G.; HOSHINO, K.; MINELLO, T. J.; ORTH, R. J.; SHERIDAN, P. F.; WEINSTEIN, M. P. The Identification, Conservation, and Management of Estuarine and Marine Nurseries for Fish and Invertebrates. BioScience, v. 51, n. 8, p. 833-641, 2001.

BEGON, M.; TOWNSEND, C. R.; HARPER, J. L. Ecology: from individuals to ecosystems. $4^{\text {th }}$ ed. Oxford: Blackwell Publishing, 2006. 759 p.

BERVOETS, L.; KNAEPKENS, G.; EENS, M.; BLUST, R. Fish community responses to metal pollution. Environ. Pollut., v. 138, n. 2, p. 338-349, 2005.

BLABER, S. J. M.; BLABER, T. G. Factors affecting the distribution of juvenile estuarine and inshore fish. J. Fish Biol., v. 17, n. 2, p. 143-162, 1980.

BLABER, S. J. M.; BREWER, D. T.; SALINI, J. P. Species composition and biomass of fishes in different habitats of a tropical northern Australia estuary: their occurrence in the adjoining sea and estuarine dependence. Estuar. Coast. Shelf Sci., v. 29, n. 6, p. 509-531, 1989.

BOLZAN, M. S.; ANDRADE, R.; SPACH, H. L.; HOSTIMSILVA, M. Range extension of Rhinosardinia bahiensis (Steindachner, 1879) in the southwestern Atlantic: The role of shallow estuarine waters in seasonal recruitment. Pan-Am. J. Aquat. Sci., v. 9, n. 4, p. 320-323, 2014.

BORDON, I. C. A. C.; SARKIS, J. E. S.; GOBBATO, G. M.; HORTELlANIA, M. A.; PEIXOTO, C. M. Metal Concentration in Sediments from the Santos Estuarine System: a Recent Assessment. J. Braz. Chem. Soc., v. 22, n. 10, p. 1858-1865, 2011.

BORJA, A., FRANCO, J.; VALENCIA, V.; BALD, J.; MUXIKA, I.; BELZUNCE, M. J.; SOLAUN, O. Implementation of the European Water Framework Directive from the Basque Country (northern Spain): a methodological approach. Mar. Pollut. Bull., v. 48, n. 3-4, p. 209-218, 2004.

CAMARGO, M.; ISAAC, V. Reproductive biology and spatiotemporal distribution of Stellifer rastrifer, Stellifer naso and Macrodon ancylodon (Sciaenidae) in the Caeté Estuary, Northern Brazil. Braz. J. Oceanogr., v. 53, n. 1-2, p. 13-21, 2005.

CARPENTER, K. E. The living marine resources of the Western Central Atlantic. Volume 2: Bony fishes part 1 (Acipenseridae to Grammatidae). Rome: Food and Agriculture Organization of the United Nations, 2002a. p. 602-1373.

CARPENTER, K. E. The living marine resources of the Western Central Atlantic. Volume 3: Bony fishes part 2 (Opistognathidae to Molidae), sea turtles and marine mammals. Rome: Food and Agriculture Organization of the United Nations, 2002b. p. 1375-2127.

CARVALHO-NETO, R. N. F.; CASTRO, A. C. L. Diversidade das assembleias de peixes estuarinos da Ilha dos Caranguejos, Maranhão. Arq. Ciênc. Mar., v. 41, p. 48-57, 2008.
CASTRO, A. C. L. Diversidade da assembléia de peixes em igarapés do estuário do Rio Paciência (MA - Brasil). Atlântica, Rio Grande, v. 23, p. 39-46, 2001.

CATALOG OF FISHES. World Wide Web electronic publication. Available at: <http://researcharchive.calacademy.org/ research/Ichthyology/catalog $>$. Accessed: 2015/10/01.

CHAO, L. N.; PEREIRA, L. E.; VIEIRA, J. P. Estuarine fish community of the dos Patos Lagoon, Brazil. A baseline study. In: YÁNEZ-ARANCIBIA, A. (Ed.). Fish community and ecology in estuaries and coastal lagoons: towards and ecosystem integration. Mexico: UNAM Press, 1985. p. 429450.

CHAVES. P. T. C.; COVA-GRANDO, G.; CALluF, C. C. H. Demersal ichthyofauna in a continental shelf region on the south coast of Brazil exposed to shrimp trawl fisheries. Acta Biol. Paran., v. 32, n. 1-4, p. 69-82, 2003.

CLARKE, K. R.; WARWICK, R. M. Change in marine communities: an approach to statistical analysis and interpretation. $2^{\text {nd }}$ ed. Plymouth: PRIMER-E, 2001.

COATES, S.; WAUGH, A.; ANWAR, A.; ROBSON, M. Efficacy of a multi-metric fish index as an analysis tool for the transitional fish component of the Water Framework Directive. Mar. Pollut. Bull., v. 55, n. 1-6, p. 225-240. 2007.

COELHO, J. A. P.; GRAÇA LOPES, R.; RODRIGUES, E. S.; PUZZI, A. Relação peso-comprimento e tamanho de início de primeira maturação gonadal para o Sciaenidae Stellifer rastrifer (Jordan, 1889), no litoral do estado de São Paulo. Bol. Inst. Pesca, v. 12, n. 2, p. 99-107, 1985.

CONTENTE, R. F.; STEFANONI, M. F.; SPACH, H. L. Fish community structure in an estuary of the Atlantic Forest biodiversity hotspot (southern Brazil). Ichthyol. Res., v. 58, n. 1, p. 38-50, 2010.

COSTA, P. F.; SCHULZ, U. H. The fish community as an indicator of biotic integrity of the streams in the Sinos River basin, Brazil. Braz. J. Biol., v. 70, n. 4 (suppl.), p. 1195-1205, 2010.

DAJOZ, R. Ecologia Geral. 2 ${ }^{\text {a }}$ ed. São Paulo: Vozes, 1973. 472 p.

DIAS, A. M.; TEJERINA-GARRO, F. L. Changes in the structure of fish assemblages in streams along an undisturbed-impacted gradient, upper Paraná River basin, Central Brazil. Neotrop. Ichthyol., v. 8, n. 3, p. 587-598, 2010.

DIAS, J. F.; GONÇALVES, A. M.; FERNANDEZ, W. S.; SILBIGER, H. L. N.; FIADI, C. B.; SCHMIDT, T. C. S. Ichthyofauna in an estuary of the Mataripe area, Todos os Santos bay, Bahia, Brazil. Braz. J. Oceanogr., v. 59, n. 1, p. 75-95, 2011.

DIAS, J. F.; PERES-RIOS, E.; CHAVES, P. T. C.; ROSSIWONGTSCHOWSKI, C. L. D. B. Análise macroscópica dos ovários de teleósteos: problemas de classificação e recomendações de procedimentos. Rev. Bras. Biol., v. 58, n. 1, p. 55-69, 1998.

EICHLER, P. P. B.; EICHLER, B. B.; DAVID, C. J.; MIRANDA, L. B.; SOUZA, E. C. P. M. The estuary ecosystem of Bertioga, São Paulo, Brazil. J. Coast. Res., v. 2, n. 39, p. 1110-1113, 2004.

EICHLER, P. P. B.; EICHLER, B. B.; MIRANDA, L. B.; RODRIGUES, A. R. Modern foraminiferal facies in a subtropical estuarine Channel, Bertioga, São Paulo, Brazil. J. Foramin. Res., v. 37, n. 3, p. 234-247, 2007.

ELLIOT, M.; WHITFIELD, A. K.; POTTER, I. C.; BLABER, S. J. M.; CYRUS, D. P.; NORDLIE, F. G.; HARRISON, T. D. The 
guild approach to categorizing estuarine fish assemblages: a global review. Fish Fish., v. 8, p. 241-268, 2007.

FALCÃO, M. G.; PICHLER, H. A.; FÉLIX, F. C.; SPACH, H. L.; BARRIL, M. E.; ARAÚJO, K. C. B.; GODEFROID, R. S. A ictiofauna como indicador de qualidade ambiental em planícies de maré do complexo estuarino de Paranaguá, Brasil. Cad. Esc. Saúde Ciênc. Biol., v. 1, p. 1-16, 2008.

FELIX, F. C.; SPACH, H. L.; HACKRADT, C. W.; MORO, P. S.; ROCHA, D. C. Abundância sazonal e a composição da assembleia de peixes em duas praias estuarinas da Baía de Paranaguá, Paraná. Rev. Bras. Zoociênc., v. 8, n. 1, p. 35-47, 2006.

FIGUEIREDO, J. L.; MENEZES, N. A. Manual de peixes marinhos do sudeste do Brasil. II. Teleostei (1). São Paulo: Museu de Zoologia da Universidade de São Paulo, 1978. 110 p.

FIGUEIREDO, J. L.; MENEZES, N. A. Manual de peixes marinhos do sudeste do Brasil. III. Teleostei (2). São Paulo: Museu de Zoologia da Universidade de São Paulo, 1980. 90 p.

FIGUEIREDO, J. L.; MENEZES, N. A. Manual de peixes marinhos do sudeste do Brasil. VI. Teleostei (5). São Paulo: Museu de Zoologia da Universidade de São Paulo, 2000. 116 p.

FROESE, R.; PAULY, P. FishBase. World Wide Web electronic publication. Available at: <www.fishbase.org $>$. Accessed: 2015/02/08.

FÚlFARO, V. J.; PONÇANO, W. L. Sedimentação atual do estuário e baía de Santos: um modelo geológico aplicado a projetos de expansão da zona portuária. In: Congresso Brasileiro de Geologia de Engenharia. Rio de Janeiro: Anais do I Congresso Brasileiro de Geologia de Engenharia, 1976. p. 67-87.

GOMES, U. L.; SIGNORI, C. N.; GADIG, O. B. F.; SANTOS, H. R. S. Guia para identificação de tubarões e raias do Rio de Janeiro. Rio de Janeiro: Technical Books, 2010. 234 p.

GONÇALVES, C. S.; BRAGA, F. M. S. Diversidade e ocorrência de peixes na área de influência da UHE Mogi Guaçu e lagoas marginais, bacia do alto Rio Paraná, São Paulo, Brasil. Biota Neotrop., v. 8, n. 2, p. 103-114, 2008.

GONÇALVES, C.; FIGUEIRA, R. C. L.; SARTORETTO, J. R.; SALAROLI, A. B.; RIBEIRO, A. P.; FERREIRA, P. A. L.; MAHIQUES, M. M. Reconstruction of historical trends in potentially toxic elements from sediment cores collected in Bertioga channel, southeastern Brazil. Braz. J. Oceanogr., v. 61, n. 2, p. 149-160, 2013.

HARRISON, T. D.; WHITFIELD, A. K. A multi-metric fish index to assess the environmental condition of estuaries. $J$. Fish Biol., v. 65, n. 3, p. 683-710, 2004.

HOSTIM-SILVA, M.; LIMA, A. C.; SPACH, H. L.; PASSOS, A. C.; SOUZA, J. D. Estuarine demersal fish community from a transition region between the tropics and the subtropics of the South Atlantic. Biotemas, v. 26, n. 3, p. 153-161, 2013.

KARR, J. R. Assessment of biotic integrity using fish communities. Fisheries, v. 6, n. 6, p. 21-27, 1981.

KING, M. G. Fisheries biology: assessment and management. Oxford: Blackwell Science, 1995. 341 p.
KUPSCHUS, S.; TREMAIN, D. Associations between fish assemblages and environmental factors in nearshore habitats of a subtropical estuary. J. Fish Biol., v. 58, n. 5, p. 13831403, 2001.

LAMPARELLI, M. L.; COSTA, M. P.; PRÓSPERI, V. A.; BEVILÁCQUA, J. E.; ARAUJO, R. P. A.; EYSINK, G. G. L.; POMPEIA, S. Sistema Estuarino de Santos e São Vicente. São Paulo: Technical Report CETESB, 2001. 178 p.

LOWE-MCCONNELL, R. H. Estudos ecológicos de comunidades de peixes tropicais. São Paulo: EDUSP, 1999. $534 \mathrm{p}$.

MARCENIUK, A. P. Chave para identificação das espécies de bagres marinhos (Siluriformes, Ariidae) da costa brasileira. Bol. Inst. Pesca, São Paulo, v. 31, n. 2, p. 89-101, 2005.

MARCENIUK, A. P.; MENEZES, N. A. Systematics of the family Ariidae (Ostariophysi, Siluriformes), with a redefinition of the genera. Zootaxa, v. 1416, p. 1-126, 2007.

MARSHALL, S.; ELLIOTT, M. Environmental influence on the fish community of the Humber estuary, U. K. Estuar. Coast. Shelf Sci., v. 46, n. 2, p. 175-184, 1998.

MARTINHO, F.; VIEGAS, I.; DOLBETH, M.; LEITÃO, H. N.; CABRAL, H. N.; PARDAL, M. A. Assessing estuarine environmental quality using fish-based indices: Performance evaluation under climatic instability. Mar. Pollut. Bull., v. 56, n. 11, p. 1834-1843, 2008.

MENEZES, N. A. Checklist dos peixes marinhos do Estado de São Paulo, Brasil. Biota Neotrop., v. 11, supl.1, p. 33-46, 2011.

MENEZES, N. A.; BUCKUP, P. A.; FIGUEIREDO, J. L.; MOURA, R. L. Catálogo das espécies de peixes marinhos do Brasil. São Paulo: Museu de Zoologia, USP; EDUSP, 2003. $160 \mathrm{p}$.

MENEZES, N. A.; FIGUEIREDO, J. L. Manual de peixes marinhos do sudeste do Brasil. IV. Teleostei (3). São Paulo: Museu de Zoologia da Universidade de São Paulo, 1980. 96 p.

MENEZES, N. A.; FIGUEIREDO, J. L. Manual de peixes marinhos do sudeste do Brasil. V. Teleostei (4). São Paulo: Museu de Zoologia da Universidade de São Paulo, 1985. 105 p.

MENEZES, N. A.; NIRCHIO, M.; OLIVEIRA, C.; SICCHARAMIREZ, R. Taxonomic review of the species of Mugil (Teleostei: Perciformes: Mugilidae) from the Atlantic South Caribbean and South America, with integration of morphological, cytogenetic and molecular data. Zootaxa, v. 3918, n. 1, p. 1-38, 2015.

MIRANDA, L. B.; CASTRO, B. M.; KJERFVE, B. Circulation and mixing due to tidal forcing in the Bertioga Channel, São Paulo, Brazil. Estuaries, v. 21, n. 2, p. 204-214, 1998.

MISHIMA, M.; TANJI, S. Maturação e desova dos bagres marinhos (Osteichthyes, Ariidae) do complexo lagunar de Cananéia $\left(25^{\circ} \mathrm{S}, 48^{\circ} \mathrm{W}\right)$. Bol. Inst. Pesca, v. 10, p. 129-141, 1983.

OTERO, M. E. B.; SPACH, H. L.; PICHLER, H. A.; QUEIROZ, G. M. L. N.; SANTOS, C.; SILVA, A. L. C. O uso de atributos das assembleias de peixes para avaliar a integridade biótica em hábitats rasos das baías de Antonina e Paranaguá, Paraná. Acta Biol. Par., v. 35, n. 1-2, p. 69-82, 2006. 
PASSOS, A. C.; CONTENTE, R. F.; ABBATEPAUlO, F. V.; SPACH, H. L.; ARAUJO, C. C. V.; JOYEUX, J. C.; CARTAGENA, B. F. C.; FÁVARO, L. F. Analysis of fish community in sectors along a salinity gradient based on species, families and functional groups. Braz. J. Oceanogr., v. 61, n. 4, p. 251-264, 2013.

PINTO, B. C. T., ARAÚJO, F. G. Assessing of biotic integrity of the fish community in a heavily impacted segment of a Tropical River in Brazil. Braz. Arch. Biol. Technol., v. 50, n. 3, p. 489-502. 2007.

PINTO, B. C. T., ARAÚJO, F. G., HUGHES, R. M. Effects of landscape and riparian condition on a fish index of biotic integrity in a large southeastern Brazil river. Hydrobiologia, v. 556, n. 1, p. $69-83.2006$ a.

PINTO, B. C. T.; PEIXOTO, M. G.; ARAÚJO, F. G. Effects of the proximity from an industrial plant on fish assemblages in the rio Paraíba do Sul, southeastern Brazil. Neotrop. Ichthyol., v. 4, n. 2, p. 269-278, 2006 b.

PORCARO, R. R.; ZANI-TEIXEIRA, M. L.; KATSURAGWA, M.; NAMIKI, C.; OHKAWARA, M. H.; FAVERO, J. M. D. Spatial and temporal distribution patterns of larval sciaenids in the estuarine system and adjacent continental shelf off Santos, Southeastern Brazil. Braz. J. Oceanogr., v. 62, n. 2, p. 146-164, 2014.

RICE, J. C. Evaluating fishery impacts using metrics of community structure. ICES J. Mar. Sci., v. 57, p. 682-688, 2000 .

ROCHA, G. R. A.; FREIRE, K. M. F. Biology and dominance relationships of the main fish species in the Lake Encantada, Ilhéus, Brazil. Acta Limnol. Bras., v. 21, n. 3, p. 309-316, 2009.

ROCHA, M. L. F.; DIAS, J. F. Inventory of Chondrichthyes and Actinopterygii species collected in the central coast of São Paulo State, Brazil. Biota Neotrop., v. 15, n. 2, p. 1-10, 2015.

RUEDA, M.; DEFEO, O. Linking fishery management and conservation in a tropical estuarine lagoon: biological and physical effects of an artisanal fishing gear. Estuar. Coast. Shelf Sci., v. 56, n. 5-6, p. 935-942, 2003.

SILVA, P. S. C.; DAMATTO, S. R.; MALDONADO, C.; FÁVARO, D. I.; MAZZILLI, B. P. Metal distribution in sediment cores from São Paulo State Coast, Brasil. Mar. Pollut. Bull., v. 62, n. 5, p. 1030-1039, 2011.

SCHMIDT, T. C. S.; MARTINS, I. A.; REIGADA, A. L. D.; DIAS, J. F. Taxocenose de bagres marinhos (Siluriformes, Ariidae) da região estuarina de São Vicente, SP, Brasil. Biota Neotrop., v. 8, n. 4, p. 73-81, 2008.

SCHWARZ JR, R.; FRANCO, A. C. N. P.; SPACH, H. L.; SANTOS, C.; PICHLER, H. A.; QUEIROZ, G. M. L. N. Variação da estrutura espacial da ictiofauna demersal capturada com rede de arrasto de porta na baía dos Pinheiros, PR. Bol. Inst. Pesca, v. 33, n. 2, p. 157-169, 2007.

SCHWARZ JR, R.; FRANCO, A. C. N. P.; SPACH, H. L.; SARPEDONTI, V.; PICHLER, H. A.; QUEIROZ, G. M. L. N. Composição e estrutura da ictiofauna demersal na baía dos Pinheiros, Paraná. Braz. J. Aquat. Sci. Tech., v. 10, n. 1, p. 27-39, 2006.

SOARES, L. S.; SILVA JÚNIOR, M. G.; CASTRO, A. C. L.; SAINT-PAUL, U. Comunidade de peixes como indicador de qualidade ambiental de alguns canais de maré do estuário do rio Paciência, São Luís - MA. Bol. Lab. Hidrobiol., v. 24, n. 1, p. 1-12, 2011.

SOUSA, E. C. P. M.; ZARONI, L. P.; GASPARRO, M. R.; PEREIRA, C. D. S. Review of Ecotoxicological Studies of the Marine and Estuarine Environments of the Baixada Santista (São Paulo, Brazil). Braz. J. Oceanogr., v. 62, n. 2, p. 133-147, 2014.

VASCONCELOS, R. P.; REIS-SANTOS, P.; TANNER, S.; MAIA, A.; LATKOCZY, C.; GÜNTHER, D.; COSTA, M. J.; CABRAL, H. Evidence of estuarine nursery origin of five coastal fish species along the Portuguese coast through otolith elemental fingerprints. Estuar. Coast. Shelf Sci., v. 79, n. 2, p. 317-327, 2008.

VAZZOLER, A. E. A. M. Biologia da reprodução de peixes teleósteos: teoria e prática. Maringá: EDUEM, 1996. 169 p.

VIANA, A. P.; LUCENA FRÉDOU, F. Ichthyofauna as bioindicator of environmental quality in an industrial district in the amazon estuary, Brazil. Braz. J. Biol., v. 74, n. 2, p. 315-324, 2014.

VILAR, C. C.; JOYEUX, J.-C.; GIARRIZZO, T.; SPACH, H.L.; VIEIRA, J.P.; VASKE-JUNIOR, T. Local and regional ecological drivers of fish assemblages in Brazilian estuaries. Mar. Ecol. Prog. Ser., v. 485, p. 181-197, 2013.

WARWICK, R. M. A new method for detecting pollution effects on marine macrobenthic communities. Mar. Biol., v. 92, n. 4, p. 557-562, 1986.

WARWICK, R. M.; PEARSON T. H.; RUSWAHYUNI. Detection of pollution effects on marine macrobenthos: further evaluation of the species abundance/biomass method. Mar. Biol., v. 95, n. 2, p. 193-200, 1987.

WHITFIELD, A. K. An estuary-association classification for the fishes of southern Africa. S. Afr. J. Sci., v. 90, n. 7, p. 411-416, 1994.

WORLD REGISTER OF MARINE SPECIES (WorMS). World Wide Web electronic publication. Available at: $<\mathrm{http}$ //www. marinespecies.org>. Accessed: 2015/05/16.

ZAR, J. H. Biostatistical Analysis. $4^{\text {th }}$ ed. New Jersey: Prentice Hall, 1999. 663 p. 